\title{
Reggie-1 and reggie-2, two cell surface proteins expressed by retinal ganglion cells during axon regeneration
}

\author{
Thomas Schulte ${ }^{1}$, Katja A. Paschke ${ }^{1}$, Ute Laessing1, Friedrich Lottspeich ${ }^{2}$ and Claudia A. O. Stuermer ${ }^{\star}$ \\ ${ }^{1}$ Faculty of Biology, University of Konstanz, D-78434 Konstanz, Germany \\ ${ }^{2}$ Max-Planck-Institute for Biochemistry, D-82152 Martinsried, Germany \\ *Author for correspondence (e-mail: Claudia.Stuermer@uni-konstanz.de)
}

\section{SUMMARY}

Fish - in contrast to mammals - regenerate retinal ganglion cell axons when the optic nerve is severed. Optic nerve injury leads to reexpression of proteins, which typically are first expressed in newly differentiated retinal ganglion cells and axons. Here we identified two new proteins of fish retinal ganglion cells, reggie-1 and reggie-2, with monoclonal antibody M802 and molecular cloning techniques. In normal fish, M802 stained the few retinal axons derived from newborn ganglion cells which in fish are added lifelong to the retinal margin. After optic nerve injury, however, M802 labeled all retinal ganglion cells and retinal axons throughout their path into tectum. Consistent with M802 staining, reggie-1 and reggie- $2 \mathrm{mRNAs}$ were present in lesioned retinal ganglion cells, as demonstrated by in situ hybridization, but were not detectable in their normal mature counterparts. In western blots with membrane

\section{INTRODUCTION}

Neurons in the central nervous system (CNS) of fish and mammals respond differently to injury. When the optic nerve is severed, nearly all of the retinal ganglion cells (RGCs) of fish survive (Meyer et al., 1985; Skene, 1989), upregulate RNA and protein production (Grafstein and McQuarrie, 1978; Grafstein, 1991) and provide growth-associated proteins to their successfully regenerating axons (Benowitz et al., 1981; Benowitz and Lewis, 1983; Burmeister et al., 1985; Perry et al., 1987; Stuermer et al., 1992). This demonstrates their unique ability (competence) to reactivate the cellular machinery required for axon regrowth. In mammals, only a small number of RGCs display such a response while the majority of the RGCs dies (Aguayo et al., 1991; Doster et al., 1991).

Molecules re-expressed by lesioned RGCs in fish are, for instance, Gap-43 (Benowitz and Lewis, 1983; LaBate and Skene, 1989) and cell adhesion molecules (CAMs) of the immunoglobulin superfamily (NCAM 180/140: Bastmeyer et al., 1990; neurolin: Paschke et al., 1992; Laessing et al., 1994; E 587 antigen: Vielmetter et al., 1991; Bastmeyer et al., 1995), which subserve functions in axon growth and navigation.

These proteins are first expressed in newly differentiating proteins of the adult goldfish brain, M802 recognizes a $48 \times 10^{3} M_{\mathrm{r}}$ protein band. At the amino acid level, $48 \times 10^{3} M_{\mathrm{r}}$ reggie- 1 and reggie- 2 are $44 \%$ identical, lack transmembrane and membrane anchor domains, but appear membrane associated by ionic interactions. Reggie-1 and reggie-2 are homologous to $35 \times 10^{3} M_{r}$ ESA (human epidermal surface antigen) but are here identified as neuronal surface proteins, present on newly differentiated ganglion cells at the retinal margin and which are reexpressed in mature ganglion cells upon injury and during axonal regeneration.

Key words: cDNA sequence, cell surface protein, goldfish, optic nerve regeneration, visual pathway, CNS, fish, retinal ganglion, reggie-1, axon regeneration 
M802 staining on the regenerating axons in the optic nerve and tectum was delayed compared to the CAMs.

Two full-length cDNAs, reggie-1 and reggie-2, were cloned. Both reggie-1 and reggie- 2 mRNA expression was found to be induced by optic nerve transection in all RGCs. This, together with the association of reggie proteins with the surface of regenerating RGC axons, implies a role of reggie-1 and reggie2 in axon regeneration.

Part of this work was published as abstracts (Schulte et al., 1994, 1995).

\section{MATERIALS AND METHODS}

\section{Production of antibodies}

Proteins were extracted with n-octylglucopyranoside (Sigma) (3\% in PBS (phosphate-buffered saline)) from a membrane fraction of 100 goldfish optic nerves, 4 weeks after ONS (OG-extract) and reconstituted in liposomes as described (Vielmetter et al., 1991). A female 6week-old balb/c mouse was injected intraperitoneally with $100 \mu \mathrm{l} \mathrm{OG-}$ extract (containing $750 \mu \mathrm{g} / \mathrm{ml}$ protein) and $200 \mu \mathrm{l}$ complete adjuvant (Sebak). Immunization was repeated 4 times with incomplete adjuvant in 3 week intervals. Hybridoma cells were produced 3 days after the last injection which was intravenous.

Hybridoma cells producing mAb M802 (mouse IgG1), were raised in RPMI (Gibco) medium under standard cell culture conditions (Vielmetter et al., 1991). Supernatants of M802 producing hybridomas were collected, brought to $1.5 \mathrm{M} \mathrm{NaCl}$ and $100 \mathrm{mM}$ sodium borate ( $\mathrm{pH}$ 8.9), and passed over a Protein-A column (Pharmacia). The column was washed with $1.5 \mathrm{M} \mathrm{NaCl}, 10 \mathrm{mM}$ sodium borate $(\mathrm{pH} 8.9)$ and antibody was eluted with $50 \mathrm{mM}$ sodium citrate $(\mathrm{pH} 3.5)$. Antibody containing fractions were pooled and concentrated using ultrafiltration tubes (Filtron).

Rabbits were immunized 4 times with recombinant reggie- 1 and reggie- 2 , respectively $(200 \mu \mathrm{g} / 0.5 \mathrm{ml}$ subcutaneously), first time with RIBI complete and subsequently with RIBI incomplete as adjuvant. The polyclonal antibodies were 504 against reggie- 1 and 513 against reggie-2. Polyclonal antibody 504 was affinity purified over a $\mathrm{CNBr}$ sepharose column (Pharmacia) with immobilized reggie-1 protein prior to use in immunostaining and Western blot experiments.

\section{Animals}

Goldfish (adults and larvae) were maintained in aquaria at the University of Konstanz. The optic nerves of adult goldfish (5-8 cm long) were cut under MS 222 (Sigma) anesthesia in compliance with animal welfare legislation.

\section{Immunohistochemistry}

Retinae were isolated from adult goldfish eyes and attached to nylon filters (Hybond N, Amersham). Unfixed retinae were exposed to the primary antibody (1 hour at room temperature), then fixed in methanol $\left(-20^{\circ} \mathrm{C}, 5\right.$ minutes), rinsed in PBS and incubated with the secondary antibody. In some experiments, flat-mounted retinae were fixed prior to treatment with primary and secondary antibodies.

Unfixed tissue (brain, optic nerve, retina) from normal adult goldfish and from fish whose optic nerves had been cut at various times prior to preparation were embedded in Tissue-Tek (Miles) and immediately frozen in liquid nitrogen. $10 \mu \mathrm{m}$ transverse cryostat sections were collected on poly-L-lysine-coated slides, air dried for 1 hour, dehydrated for 5 minutes in methanol $\left(-20^{\circ} \mathrm{C}\right)$ and rinsed at room temperature in PBS $(3 \times 5$ minutes). Sections were incubated with mAb M802 overnight at $4^{\circ} \mathrm{C}$, washed in PBS for 5 minutes, incubated $\left(1\right.$ hour at $37^{\circ} \mathrm{C}$ ) with fluoresceine isothiocyanate (FITC)conjugated goat anti-mouse secondary antibody (Dianova), and rinsed in PBS ( $3 \times 5$ minutes). Retina whole mounts were double labeled by
M802 and rabbit antisera against recombinant reggie-1 and reggie-2, respectively, by either of two methods: unfixed retinae were incubated ( 1 hour) in rabbit antiserum, rinsed in PBS ( $3 \times 10$ minutes), fixed in methanol $\left(-20^{\circ} \mathrm{C}, 5\right.$ minutes), rinsed in PBS ( $3 \times 10$ minutes), and then exposed to M802 (1 hour, $\left.37^{\circ} \mathrm{C}\right)$. Following repeated rinses in PBS, secondary antibodies, FITC-conjugated goat anti-mouse and rhodamin (RITC)-conjugated goat anti-rabbit were added (1 hour, room temperature). Fixed retinae were incubated in rabbit antiserum overnight and then treated as described above. Retina whole mounts and sections were coverslipped in a mixture of $5 \mathrm{~g}$ Moviol 4-88 (Hoechst), $20 \mathrm{ml} \mathrm{PBS,} 10 \mathrm{ml}$ glycerol, saturated with n-propyl-gallate. Immunostained tissue was viewed and photographed at a Zeiss Axiophot equipped with the appropriate filter sets. Culturing and immunostaining of retinal explants was performed as described earlier (Vielmetter and Stuermer, 1989).

\section{Immunoblotting}

Proteins were released from a fraction of membranes of total adult goldfish brains, prepared as described (Vielmetter et al.,1991), by treating the membranes with $10 \mathrm{mM}$ Tris- $\mathrm{HCl}(\mathrm{pH}$ 7.4) containing either $500 \mathrm{mM} \mathrm{NaCl}$, or $3 \%$ n-octylglucopyranoside, or $2 \%$ Triton $\mathrm{X}$ 100.

To analyse native and recombinant proteins, $50 \mu \mathrm{g}$ of total membrane protein fractions or $0.2 \mu \mathrm{g}$ of recombinant reggie- 1 and reggie-2 were subjected to $10 \%$ SDS-PAGE (Laemmli, 1970). Separated proteins were transferred to nitrocellulose membranes (Towbin et al., 1979) and blocked with $3 \%$ bovine serum albumin (BSA) in PBS with $0.05 \%$ Tween-20 (PBST). The filters were incubated with M802 $(50 \mu \mathrm{g} / \mathrm{ml})$ in $1 \%$ BSA/PBST, washed in PBST and incubated with a rabbit anti-mouse peroxidase-conjugated secondary antibody. Alternatively, filters were incubated with the rabbit antiserum against recombinant reggie-1 or reggie-2 $(2 \mu \mathrm{g} / \mathrm{ml})$ at a dilution of 1:1000 in 1\% BSA/PBST. Detection was with goat anti-rabbit peroxidase-conjugated secondary antibody $(2 \mu \mathrm{g} / \mathrm{ml}$, Dianova). After washing in PBST filters were developed using the ECL detection system (Amersham).

\section{Purification of reggie protein}

M802 antibody was coupled to Mini-Leak (KenEmTec) agarose at a concentration of $5 \mathrm{mg} / \mathrm{ml}$ according to the manufacturer's instructions. All steps were carried out at $4^{\circ} \mathrm{C}$ and $\mathrm{pH}$ of solutions was adjusted at room temperature. $100 \mathrm{~g}$ larval goldfish (30-60 days old) were homogenized with a Polytron homogenizer (Bachofer) in 300 $\mathrm{ml}$ TNCE (140 mM NaCl, $50 \mathrm{mM}$ Tris $\mathrm{pH} 7.4,2 \mathrm{mM} \mathrm{CaCl} 2,1 \mathrm{mM}$ EDTA, $1 \mathrm{mM}$ PMSF, $0.02 \mu \mathrm{M}$ aprotinin, $1 \mu \mathrm{M}$ leupeptin, $1 \mu \mathrm{M}$ pepstatin A, all proteinase inhibitors from Sigma), and the homogenate centrifuged at $1000 \mathrm{~g}$ for 10 minutes. The pellet was washed in $100 \mathrm{ml}$ TNCE and centrifuged again. With $10 \%$ Tween-20 (USB, United States Biochemicals) in TNCE, the supernatant was brought to $2.5 \%$ Tween-20 and centrifuged (150,000 $\mathrm{g}, 1$ hour). The resulting supernatant was discarded, the pellet washed in $100 \mathrm{ml}$ TNCE and centrifuged again at $150,000 \mathrm{~g}$ for 1 hour. The membranes were then extracted twice with TX-100 buffer (2\% Triton X-100 (Boehringer Mannheim), $150 \mathrm{mM} \mathrm{NaCl}, 20 \mathrm{mM}$ Tris pH 8.0, $2 \mathrm{mM}$ $\mathrm{CaCl}_{2}, 1 \mathrm{mM}$ EDTA with the above protease inhibitors included), in a $30 \mathrm{ml}$ Dounce homogenizer. The combined TX-100 extracts were then centrifuged at $100,000 \mathrm{~g}$ for 1 hour. The supernatant was filtered (0.45 $\mu \mathrm{m}$ Durapore-filter, Millipore) and passed over a $10 \mathrm{ml}$ M802 column overnight. The column was rinsed with 10 volumes of TX100 buffer, 10 volumes of $\mathrm{W} 1(500 \mathrm{mM} \mathrm{NaCl}, 20 \mathrm{mM}$ Tris- $\mathrm{HCl}$ (pH 8.0), $0.02 \%$ Nonidet-P40 (Boehringer Mannheim)) and 5 volumes of W2 (10 mM Tris- $\mathrm{HCl}$ (pH 8.0), 5 mM EDTA, 0.5\% n-octylglucopyranoside). Elution was carried out with $100 \mathrm{mM}$ triethylamine $(\mathrm{pH}$ $12.0)$ and $0.5 \%$ n-octylglucopyranoside. The collected fractions $(1 \mathrm{ml})$ were immediately neutralized by adding $50 \mu \mathrm{l} 2 \mathrm{M}$ Tris $\mathrm{HCl}(\mathrm{pH} 6.5)$. Aliquots $(50 \mu \mathrm{l})$ of these fractions were precipitated with $10 \%$ trichloroacetic acid (TCA), washed with $1 \mathrm{ml}-20^{\circ} \mathrm{C}$ cold acetone, 
dried and subjected to SDS-PAGE analysis. One fraction of immunopurified protein was used for the detemination of the N-terminal amino acid sequence after SDS-PAGE and transfer to Glassy bond membranes (Biometra) (Eckerskorn and Lottspeich, 1989). Protein fractions of three preparations were pooled, precipitated with $10 \%$ TCA, washed twice with $10 \mathrm{ml}$ acetone $\left(-20^{\circ}\right)$, dried in a SpeedVac. Concentrator (Bachofer) and subjected to proteolysis with endoproteinase LysC (Eckerskorn et al., 1988), as described (Laessing et al., 1994). The resulting peptide fragments RLysC 1-7 (Fig. 4) were purified by reverse phase High Performance Liquid Chromatography (HPLC) (Eckershorn et al., 1988) and sequenced using a 474A pulse liquid phase sequencer, equipped with a 120A PTH analyser (Applied Biosystems) following the manufacturer's instructions.

\section{SDS-PAGE analysis}

SDS-PAGE analysis was carried out with the Multiphor II Electrophoresis System (Pharmacia), on $0.5 \mathrm{~mm} 8 \%$ gels with the acidic tris/acetate/tricin buffer system (Pharmacia). After electrophoresis, the gels were silver stained (Heukeshoven, 1985).

\section{RNA isolation}

Total RNA of retinae of adult goldfish (14 days after ONS) was isolated using the RNAzol-B method (WAK-Chemie). Poly(A)+ RNA of total cellular RNA was isolated using oligo(dT)-Dyna-Beads (Dynal), with a yield of $\sim 5 \%$.

\section{Isolation of two cDNAs fragments coding for reggie}

Standard methods were used for manipulation of nucleic acids (Sambrock et al., 1989, Ausubel et al., 1980). Poly(A)+ RNA (goldfish retina, 14 days after ONS) was reverse transcribed using Superscript Reverse Transcriptase (Gibco) with an oligo(dT) primer. This cDNA first-strand reaction product was then used as a template in two Polymerase Chain Reactions (PCR) carried out with Taq polymerase (35 cycles, annealing temperature $50^{\circ} \mathrm{C}$ ). Reaction 1 , with the oligonucleotide primers 5'-CITTYAAYCARGARGTIAAYAC-3' (derived from RLysC 2, Fig. 4), and 5'-GCYTCICCRTAYTGYTGRTA-3' (derived from RLysC 1, Fig. 4) resulted in a 389 bp (base pair) product (reggie-1). Reaction 2 with the oligonucleotide primers $5^{\prime}$-TGYGGICCIAAYGARGCIATG-3' (the $\mathrm{N}$ terminus, Fig. 4) and $5^{\prime}-$ GCCATCCAIGCIGCYTCIGC-3' (peptide fragment RLysC 3, Fig. 4) gave an $1 \mathrm{~kb}$ product (reggie-2). The PCR products were subjected to agarose gel electrophoresis and visualized by ethidium-bromide fluorescence under UV-light. PCR products were then subcloned using the TA-Cloning Kit (Invitrogen).

\section{cDNA library screening}

A $\lambda$-ZAP II cDNA library of 5 day embryonic goldfish was screened with the 389 bp reggie- 1 and, in an independent experiment, with the $1 \mathrm{~kb}$ reggie-2 PCR fragment according to standard strategies (Sambrock et al., 1989; Stratagene Manual, 1989). Primary screens of $4 \times 10^{6}$ phages each resulted in the isolation of 10 primary clones for each reggie-1 and reggie- 2 . These were subjected to secondary and tertiary screening to obtain single phage clones.

\section{DNA sequencing and sequence analysis}

DNA sequencing was performed with the Sequenase Sequencing Kit (USB). Specific primers for internal sequencing were employed or clones were subjected to unidirectional deletion with the Double Stranded Nested Deletion Kit (Pharmacia) and then sequenced using M13- and reverse-primer. Sequence compressions were resolved by dITP mixes. All cDNA clones were sequenced in both the $5^{\prime}$ and $3^{\prime}$ directions.

Searches of the National Center for Biotechnology Information databases were performed with BLAST (Altschul et al., 1990) and the BLAST server service (HyperBLAST). Sequence analysis was performed by the Wisconsin Sequence Analysis Package Versions 7 or 8, and the CLUSTAL W program (Thompson et al., 1994).
cRNA as hybridization probes were produced by standard protocols with radioactive probes labeled [32P]UTP (Amersham) and nonradioactive probes labeled with the DIG RNA Labeling Kit (Boehringer Mannheim). In vitro transcribed RNAs or reggie-1 and reggie-2 were subjected to gel electrophoresis (2.2 M formaldehyde), blotted onto nylon membranes and hybridized with DIG labeled reggie-1 and reggie-2, respectively.

\section{In situ hybridization}

Isolated retinae of adult goldfish were mounted onto Hybond $\mathrm{N}+$ membranes (Amersham) and subjected to a whole-mount in situ hybridization procedure (Westerfield, 1994) based on the Boehringer DIG system. The probes were full-length sense and antisense cRNAs of reggie- 1 and reggie- 2 hydrolyzed to a mean size of 250 bases by a limited alkaline hydrolysis (Wilkinson, 1992). The specificity of the antisense cRNAs for reggie-1 and reggie-2 mRNAs was confirmed on northern blots with in vitro transcribed RNAs of reggie-1 and reggie2. The color reaction was performed with the BM Purple AP-Substrate (precipitating, Boehringer Mannheim). All in situ hybridizations were run as doublets with antisense cRNA and with sense cRNA as control. Only antisense reactions resulted in staining, and the sense controls were void.

\section{Production of recombinant reggie-1 and reggie-2 in E. coli}

For production of recombinant protein in transformed E. coli (Top10', Invitrogen), full-length PCR fragments of goldfish reggie-1 and reggie-2 were subcloned into the procaryotic expression vector pTrcHis (Invitrogen). Correct orientation and reading frame were confirmed by sequencing with the T7 Polymerase Sequencing Kit (Pharmcia). E. coli were grown at $37^{\circ} \mathrm{C}$ in $200 \mathrm{ml} \mathrm{LB}$ (Luria Betani medium) with $100 \mu \mathrm{g} / \mathrm{ml}$ ampicillin to an optical density of 0.6-0.8. Protein production was induced by adding $50 \mu \mathrm{M}$ IPTG (Isopropyl$\beta$-D-1-thiogalactopyranoside), and cultures were grown for additional 4 hours. The induced proteins were isolated as inclusion bodies under denaturing conditions by solubilization with $6 \mathrm{M}$ guanidine hydrochloride, $20 \mathrm{mM}$ sodium phosphate, $500 \mathrm{mM} \mathrm{NaCl}, \mathrm{pH} 7.8$ for 1 hour at room temperature. Cellular debris was pelleted at $10,000 \mathrm{~g}$ for 10 minutes at room temperature and the supernatant was purified over a Ni-NTA spin column (Qiagen) according to the manufacturers instructions.

\section{RESULTS}

\section{Lesion-induced expression of reggie}

mAb M802 was selected from an antibody screen in which mice had been immunized with a fraction enriched in cell surface proteins (see Materials and Methods) from regenerating goldfish optic nerves, and was subsequently used to immunopurify reggie (see below).

M802 immunostaining was performed in adult goldfish with unilateral optic nerve section (ONS) to compare reggie expression in the normal and regenerating retinotectal pathway. In retina whole mounts of the unlesioned (normal) side, M802 labeled the young and growing axons (Fig. 1A) derived from newborn RGCs at the retinal peripheral margin (Johns, 1977; Vielmetter et al., 1991). Since living cells do not allow antibodies to penetrate their membranes, successfull M802 staining of unfixed retinal whole mounts indicates that M802 binds to the cell surface. In the optic nerve and during their further path into tectum, the bundle of growing RGC axons was selectively labeled by M802 (Fig. 1H), whereas older axons in the retina, optic nerve and tectum were M802 negative (Figs $1 \mathrm{~A}, \mathrm{C}, \mathrm{F}, \mathrm{H}, 2 \mathrm{~A})$. In addition to growing RGC axons, the surface 
Fig. 1. Immunocytochemistry in the normal and regenerating goldfish retinotectal system. (A,B,D,F,G) Unfixed retinal wholemounts labeled by M802. (A,F) In the normal retina, M802 binds selectively to the young axons (small arrows in A,F) and to new RGCs at the retinal margin (larger arrow in $\mathrm{F}$ and arrow in insert). A segment of the margin is depicted in the insert in $\mathrm{F}$ (asterisk in $\mathrm{A}$, optic disc). Calibration bar in A, $200 \mu \mathrm{m}$, in F, $100 \mu \mathrm{m}$, in insert $25 \mu \mathrm{m}$. (B,D) After ONS, all or almost all RGCs (D, arrowhead) and RGC axons (arrows in B, D) are labeled (asterisk in B, optic disk). Calibration bars in B, $200 \mu \mathrm{m}$; in $\mathrm{D}, 50 \mu \mathrm{m}$. (C,E) Section through the retina, midway between the retinal margin and the optic disk. M802 labeling includes RGCs and RGC axons after ONS (E), but RGCs of normal retina (C) are not labeled. Lines at the left demarcate the upper boundary of the RGC and RGC axon layer. Calibration bars, $50 \mu \mathrm{m}$. (G) One year after ONS, M802 labels only young axons (arrow) from newborn RGCs at the retinal margin. Calibration bar, $50 \mu \mathrm{m}$. (H) Section through the optic nerve at the level of the chiasm. The previously transected nerve (lower half) exhibts M802 labeling throughout the fascicles of regenerating RGC axons. In the normal nerve (upper half), labeling is confined to the small fascicle of young and growing axons (arrow). Arrowheads point to blood vessels that are M802 positive. Calibration bar, $200 \mu \mathrm{m}$.
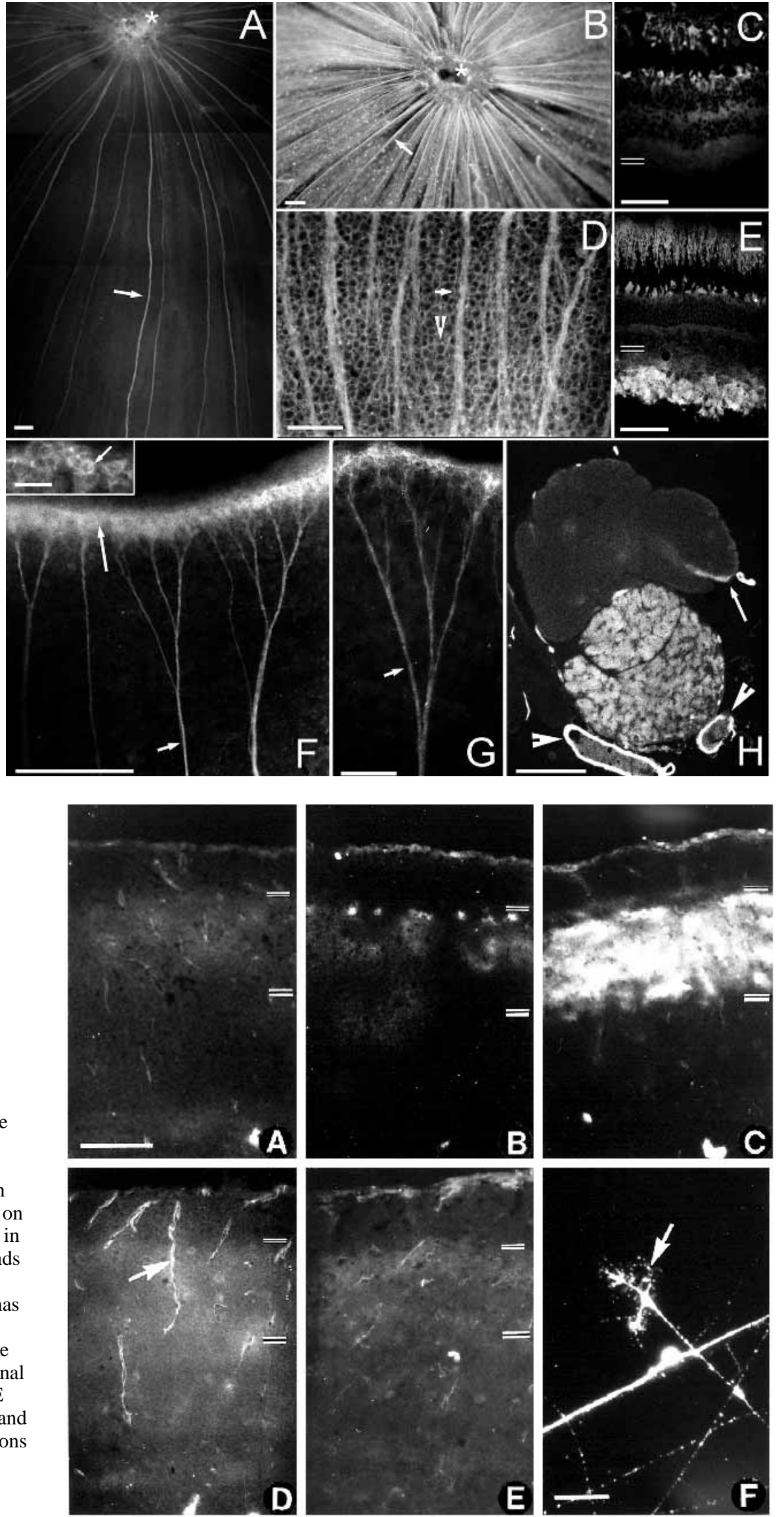

staining on their surface, including the filopodia. Calibration bar, $20 \mu \mathrm{m}$. 
of endothelial cells in CNS blood vessels and capillaries was labeled by M802, independent of whether the optic nerve was lesioned or not (Figs 1H, 2A-E).

When the optic nerve was transected, all RGCs and their axons exhibited M802 immunoreactivity. Lesion-induced expression of the M802 antigen on RGCs began between 5 and 6 days after ONS and, at this time, appeared on the retinal axons from their RGCs of origin to the site of the lesion in the optic nerve (Fig. 1B,D,E). The first regenerating i.e. newly formed axons extend from the site of lesion between 2 and 3 days after ONS (Lanners and Grafstein, 1980). They cross the lesion site and can be seen in the brain-side portion of the optic nerve by 5-9 days where they are identified by antibodies against the growth-associated CAMs E587 antigen and Neurolin (Hirsch et al., 1995). Regenerating axons reach the rostral tectum approximately 10-14 days after ONS (Stuermer and Easter, 1984b) and have reoccupied all of the retinorecipient layers of tectum, SO (Stratum opticum) and SFGS (Stratum fibrosum et griseum superficiale) by roughly 40 days and, from the earliest stages of tectal reinnervation, they express the growth-associated CAMs on their surface (Bastmeyer et al., 1990; Vielmetter et al., 1991; Paschke et al., 1992). M802 labeling, while apparent on axons at 5-6 days after ONS in the retina and in the eye-side portion of the optic nerve, was not detected at early stages when the regrowing (new) axons enter and pass through the brain-side portion of the optic nerve and reach the tectum. On the regenerating axons in the brain-side optic nerve, M802 labeling was first detectable at 18 days after ONS and was weak at 53 days in the optic tectum (Fig. 2B). Labeling had significantly increased in the nerve at 40 days (Fig. 1H) and in SO and SFGS at 70 days and more so at 129 days (Fig. 2C). Labeling persisted for at least 6 months and declined thereafter (Fig. 2D). Accordingly, one year after ONS, most axons were unlabeled except for the axons of new RGCs born intermittently at the retinal margin (Fig. 1G). Although diffuse, M802 labeling was associated with reforming RGC fascicles in the nerve (Fig. $1 \mathrm{H}$ ) and $\mathrm{SO}$ and with RGC axons in the SFGS (Fig. 2B,C). This was judged from its typical distribution (Stuermer and Easter, 1984b), from comparison with antibodies against the growth-associated CAMs (Bastmeyer et al., 1990; Vielmetter et al., 1991; Paschke et al., 1992), with the neurofilament marker mAb M501 (Paschke et al., 1992) and from analysis of fish whose eyes had been enucleated. Tecta deprived of all RGC axons by eye removal were always devoid of M802 staining (Fig. 2E). That M802 does bind to regenerating RGC axons was confirmed in tissue culture. RGC axons extending from retinal explants on a laminin substrate exhibited M802 label on their surfaces including growth cones and filopodia (Fig. 2F). Thus, reexpression of reggie protein on the regenerating portion of axons in vivo appeared delayed.

Outside the visual system, M802 recognized dorsal sensory fiber tracts of the spinal cord, the dorsal root and elongated processes, probably neurons innervating the heart and intestine. M802 also stained the skin, in adults and larvae, as well as processes in muscle, probably sensory axons, cells throughout the thymus and macrophages within the gills. Macrophages in glia cell cultures derived from lesioned optic nerves (Bastmeyer et al., 1994) were also M802 positive. However, in the lesioned optic nerve in vivo and in the tectum where macrophages are expected to be numerous and involved in removing myelin debris, M802-positive cells were not detected except for a few cells directly at the cut.

\section{Immunopurification of reggie and isolation of CDNA clones encoding reggie-1 and reggie-2}

When solubilized proteins from adult goldfish brains (OGbrain extract) were subjected to SDS-PAGE under nonreducing conditions and transferred to nitrocellulose, M802 recognized a major protein band of $48 \times 10^{3} M_{\mathrm{r}}$ and some minor bands between 30 and $48 \times 10^{3} M_{\mathrm{r}}$ which may be degradation products (Fig. 3A). After SDS-PAGE under reducing conditions, no recognition occurred. This major band corresponds to the $48 \times 10^{3}$ apparent molecular weight of the immunopurified protein on silver stained gels after SDS-PAGE under the same non-reducing conditions (see below).

From our earlier experience with isolation of growth-associated proteins from adult goldfish brains (Vielmetter et al., 1991; Paschke et al., 1992; Laessing et al., 1994), we anticipated that thousands of adult fish would be needed to obtain sufficient amounts of protein for peptide sequencing. 30- to 60day-old goldfish larvae were used in preference to adult fish brains for protein isolation because it is a more economical tissue as it eliminates the need for dissection.

Triton X-100 soluble components from membrane fractions of total larvae were applied to M802 immunoaffinity chromatography. During the course of this study, we noted that exposure of membranes to a buffer of $500 \mathrm{mM} \mathrm{NaCl}, 10 \mathrm{mM}$ Tris- $\mathrm{HCl}(\mathrm{pH} 7.4)$ and subsequent treatment with $100 \mathrm{mM}$ triethylamine ( $\mathrm{pH}$ 11.0) was sufficient for removal of a significant proportion of reggie from cell membranes. The eluted protein appeared as a $48 \times 10^{3} M_{\mathrm{r}}$ band in SDS-PAGE (Fig. 3B). Roughly $30 \mu \mathrm{g}$ of $48 \times 10^{3} M_{\mathrm{r}}$ protein was obtained from $300 \mathrm{~g}$ larvae. Purified protein was digested with endoproteinase LysC and the resulting peptides were separated by reverse phase

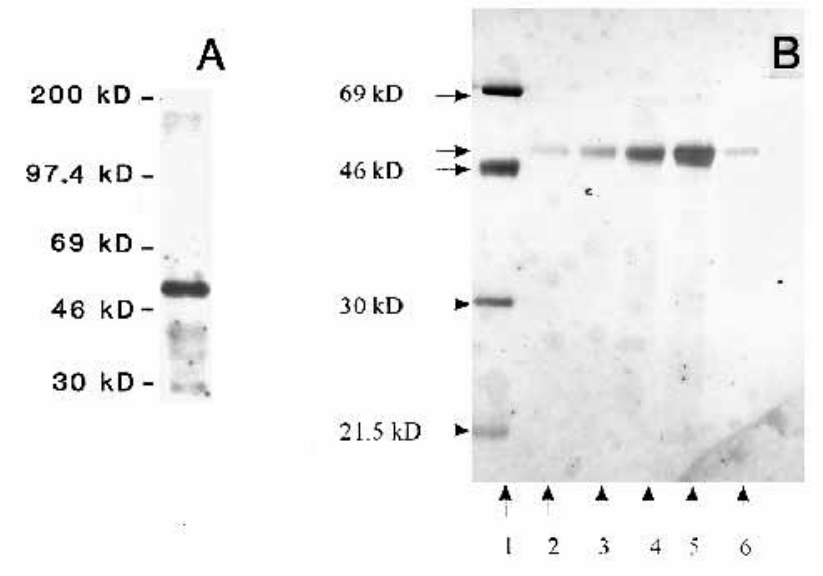

Fig. 3. Immunoblots with M 802 and elution profile of $48 \times 10^{3} M_{\mathrm{r}}$ reggie after immunoaffinity purification. (A) Immunoblots with $\mathrm{mAb}$ M802 and detergent-extracted proteins of adult goldfish brain (OGbrain extract) after separation in 10\% SDS-PAGE under nonreducing conditions and transfer to nitrocellulose. M802 recognizes a major protein band of $48 \times 10^{3} M_{\mathrm{r}}$ and some lower relative molecular mass (probably degradation) products. (B) Elution profile of the M802 immunoaffinity column. Lane 1, molecular weight markers; lanes 2-6, elution profile of the affinity column showing a protein at $48 \times 10^{3} M_{\mathrm{r}}$, visualized by silver staining after SDS-PAGE and nonreducing conditions. 


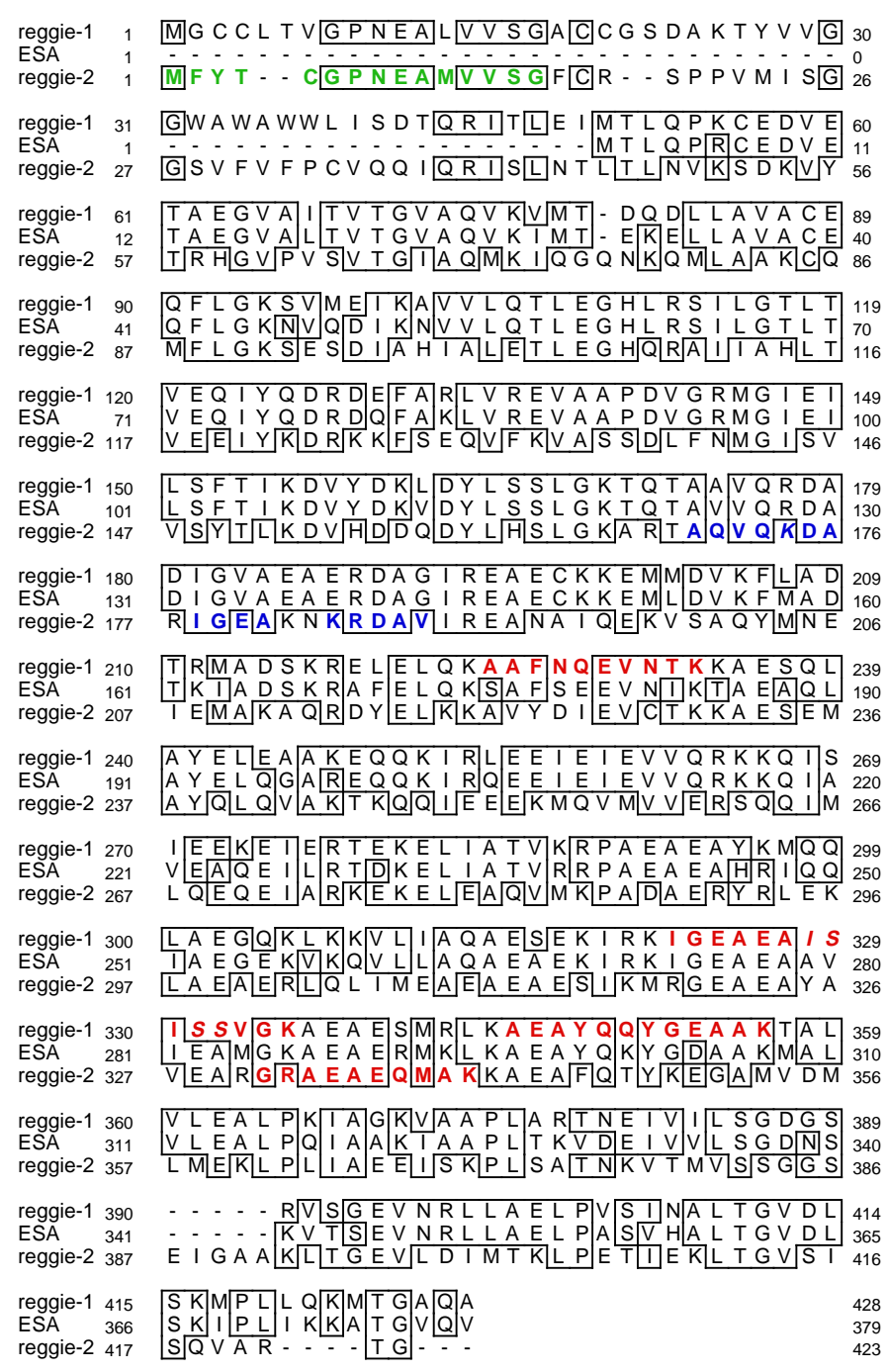

Fig. 4. Molecular characterization of reggie-1 and reggie-2. Predicted amino acid sequence of reggie-1, reggie-2 and ESA. Comparison of reggie-1, reggie-2 and ESA using the CLUSTALW program (Thompson et al., 1994). The boxed amino acid residues are identical in two or all three sequences of reggie-1, reggie-2 and ESA, respectively. The total amino acid identity is $44 \%$ between reggie- 1 and reggie-2, and $80 \%$ between reggie-1 and ESA. Dots represent gaps resulting from sequence alignment. The amino acid sequence obtained through $\mathrm{N}$-terminal microsequencing of $48 \times 10^{3} M_{\mathrm{r}}$ reggie appears in green. Amino acid sequences obtained through microsequencing are: in red, the unambiguous sequences (RLysC 14) with the sequence related to RLysC4 in italics; in blue, the ambiguous peptide sequences (RLysC 5-7) with non matching amino acids in italics. The sequence data of reggie- 1 and reggie- 2 are available from GenBank under accession numbers L 36867 and U 33556 , for reggie-1 and reggie-2, respectively.

HPLC and sequenced by Edman degradation. Four unambiguous amino acid sequences (RLysC1-C4) (Fig. 4) permitted the design of oligonucleotide primers (sense and antisense) that were used in polymerase chain reaction (PCR). In addition, three partly ambiguous amino acid sequences (RLysC5-C7) (Fig. 4) were obtained. The $\mathrm{N}$ terminus was sequenced directly and two degenerate sense primers were generated based on the $\mathrm{N}$-terminal sequence.

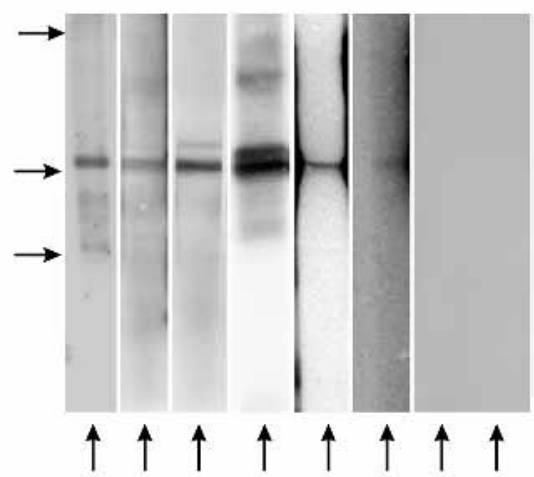

Fig. 5. Immunoblots with antisera against recombinant reggie-1 and reggie-2. Detergent extracted proteins of adult goldfish brain (OGbrain extract, $50 \mu \mathrm{g}$ protein each lane) in lanes 1, 2, 3, 7, 8; recombinant reggie-1, lane 4; recombinant reggie-2, lanes 5, 6 (100 ng each), after $10 \%$ SDS-PAGE under non-reducing condition and transfer to nitrocellulose. They were exposed to reggie-1 antiserum 504 (lanes 2, 4), to reggie-2 antiserum 513 (lanes 3, 5) and to M802 (lanes 1,6) as reference. Secondary antibodies (goat anti mouse) in lane 7 and goat anti rabbit in lane 8 served as controls. Reggie- 1 and reggie-2 antisera (lanes 2,3) recognize the same major $48 \times 10^{3} M_{\mathrm{r}}$ protein band as M802 (lane 1). Reggie-1 antiserum recognizes recombinant reggie-1 protein which appears as two bands around $48 \times 10^{3} M_{\mathrm{r}}$ (lane 4 ), and reggie-2 antiserum binds to recombinant reggie-2 (lane 5). M802 weakly recognize recombinant reggie-2 (lane 6).

A combination of primers (defined in Materials and Methods) was employed in RT-(reverse transcription) PCRbased cloning approaches with a first-strand cDNA of goldfish retinae (14-28 days after ONS) as template. This resulted in synthesis of two different products of $389 \mathrm{bp}$ and $1 \mathrm{~kb}$, respectively, encoding reggie.

A cDNA library of 5-day-old goldfish larvae was screened with each PCR fragment as probe in separate experiments. Full-length cDNAs containing the 389 bp fragment (reggie1) and the $1 \mathrm{~kb}$ fragment (reggie-2), respectively, were isolated. Of four full-length reggie-1 cDNAs, two were identical. The other two reggie-1 cDNAs exhibited minor differences in their $3^{\prime}$ non-coding region, which may be attributed to the tetraploid chromosome set of goldfish (Risinger and Larhammer, 1993).

The reggie- 1 cDNA contained the amino acid sequences $\mathrm{RLysC} 1$ and $\mathrm{RLysC} 2$, and a sequence similar to RLysC4. The latter, however, had exchanges of 3 of the 15 amino acid residues. All attempts to clone a cDNA that encoded the entire $\mathrm{RLysC} 4$ and that differed from reggie-1 were unsuccessful (see Discussion). Reggie-2 cDNA contained the N-terminal sequence and RLysC3. Also, the sequences RLysC5-C7 could be aligned to reggie- 2 .

Reggie- 1 and reggie- 2 cDNAs are $3.1 \mathrm{~kb}$ and $3.2 \mathrm{~kb}$ long, respectively. They encode proteins with the predicted molecular masses of $46.9 \times 10^{3}$ and $47.2 \times 10^{3}$, respectively, which correspond to both the $48 \times 10^{3}$ apparent molecular mass of the immunopurified protein and the protein recognized by M802 in Western blots with OG-brain extract (Fig. 5).

Recombinant reggie-1 and reggie-2 expressed by E. coli had (when subjected to SDS-PAGE under reducing conditions) 


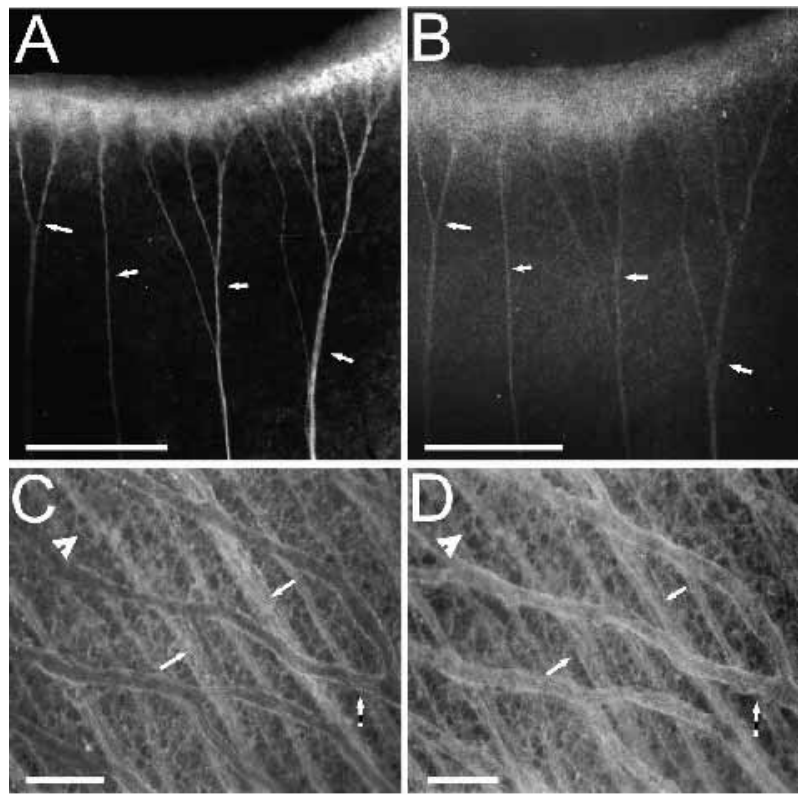

Fig. 6. Double-immunostaining with M802 and the antiserum against recombinant reggie-1 protein. $(\mathrm{A}, \mathrm{B})$ In a whole mount of a normal retina (unfixed) 504 antiserum against reggie-1 (B) and M802 (A) recognize the same new RGCs at the retinal margin and growing RGC axons (arrows) derived from the margin. Calibration bars, 100 $\mu \mathrm{m}$. (C,D) This whole mount of a retina, 14 days after ONS and with the retinal blood vessel layer left intact was fixed with methanol prior to exposure to M802 (C) and antiserum 504 against reggie-1 (D). The same structures are labeled in C,D: all RGCs (examples are marked by arrowheads), all RGC axons (long arrows) and retinal blood vessels (short arrow). Calibration bars, $50 \mu \mathrm{m}$.

apparent molecular weights of $48 \times 10^{3}$. Under non-reducing conditions, recombinant reggie-1 appeared as two bands around $48 \times 10^{3} M_{\mathrm{r}}$. In western blot experiments (Fig. 5), M802 weakly recognizes the bacterially expressed proteins, but the polyclonal antiserum 504 strongly bound to recombinant reggie-1 (but not to reggie-2) and 513 antiserum bound to reggie-2 (but not to reggie-1). Moreover, in western blots with OG-brain extract (again non-reducing conditions), reggie-1 and reggie- 2 antisera recognized the same major $48 \times 10^{3} M_{\mathrm{r}}$ protein band as M802 (Figs 3, 5).

Moreover, when applied to retinal whole mounts (unfixed or fixed), both antisera stained selectively the new RGCs at the retinal margin and the new growing axons derived from these cells (Fig. 6A,B). Double-labeling experiments with M802 and M504, or M802 and M513, confirmed that the antisera recognized the very same RGCs and RGC axons that were M802 positive (Fig. 6). Both antisera also labeled RGCs and RGC axons, 10 and 14 days after ONS. Furthermore, they labeled the retinal blood vessel layer, with stronger labeling being produced by 504 than by 513 (Fig. 6C,D). These results are consistent with the view that M802 antigen contains the two proteins, reggie-1 and reggie-2, which are coexpressed by growing axons and by endothelial cells.

\section{Reggie-1 and reggie-2 are membrane-associated proteins and homologs of human ESA}

The cDNAs of reggie- 1 and reggie- 2 are 50\% identical, and
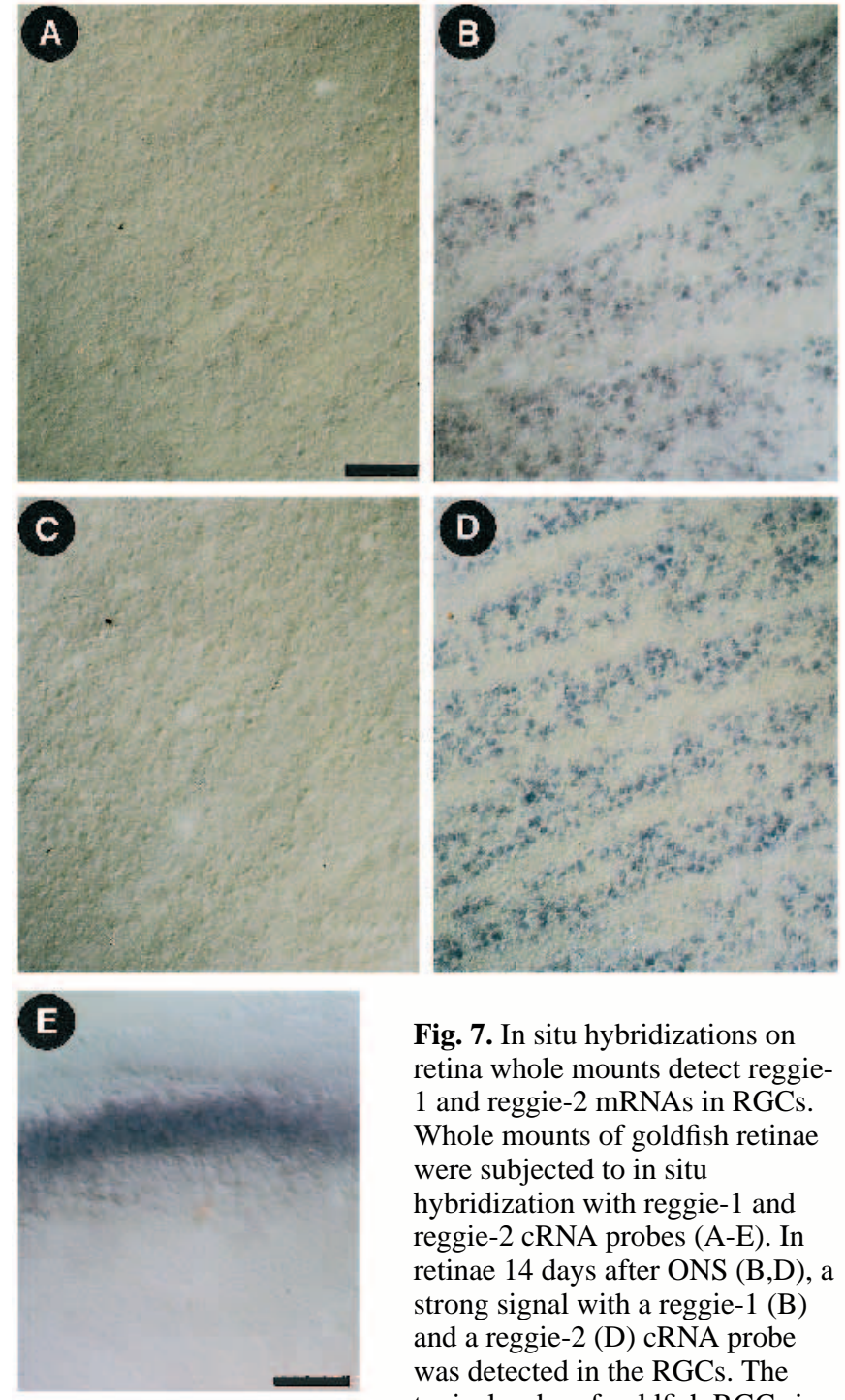

Fig. 7. In situ hybridizations on retina whole mounts detect reggie1 and reggie- 2 mRNAs in RGCs. Whole mounts of goldfish retinae were subjected to in situ hybridization with reggie-1 and reggie-2 cRNA probes (A-E). In retinae 14 days after ONS (B,D), a strong signal with a reggie-1 (B) and a reggie-2 (D) cRNA probe was detected in the RGCs. The typical order of goldfish RGCs in rows with the bundles of RGC axons between them can be recognized. No signal was seen in mature RGCs of the normal retina, either with the reggie-1 (A) or with the reggie-2 (C) cRNA probe. Calibration bar, $100 \mu \mathrm{m}$. (E) In situ hybridization signals, however, were seen in RGCs at the margin of normal retinae (here with the reggie-2 cRNA probe). Calibration bar, $50 \mu \mathrm{m}$.

the derived amino acid sequences of reggie-1 and reggie-2 (Fig. 4) show $44 \%$ identity. The full-length cDNA clone of reggie2 contained a $72 \mathrm{bp}$ intron-like insertion (not shown) at position 967 (amino acid residue 316), which included stop codons in all three reading frames. This was not observed in the $1 \mathrm{~kb}$ PCR clone nor in the PCR clone that contained the complete open reading frame and which was used for the production of recombinant reggie-2 protein. This insertion and its boundaries contain consensus sequences known for introns (GT/AG rule; Breathnach and Chambon, 1981; Mount, 1982). This insertion may either represent an unspliced intron, or it may lead to a truncated form of reggie-2 arising from nonfunctional splice sites (Stuart et al., 1987). Reggie-1 and reggie-2 encode hydrophilic proteins. Neither appears to contain a hydrophobic stretch that could represent an $\alpha$-helical transmembrane 
domain or a signal sequence. Both fail to exhibit a signal for addition of a glycosylphosphatidyl-inositol (GPI) lipid anchor (Kyte and Doolittle, 1982; Moran and Caras, 1991a,b; Englund, 1993). Sequence motifs typical for groups of cell surface proteins, such as immunoglobulin-like domains, fibronectin-type domains (William and Barclay, 1988, Piggot and Power, 1993) or epidermal growth factor (EGF) repeats (Engel, 1989) were not found. Instead, reggie-1, reggie-2 and ESA (Schroeder et al., 1994, see below) contain amino acid sequences that could form $\alpha$-helical secondary structures (Lupas et al., 1991, and A. Lupas, personal communications). Putative N-glycosylation sites were not recognized (PROSITE, EMBL). Together with biochemical data, the foregoing results suggest a cell membrane association of reggie-1 and reggie-2 by ionic interactions.

A $35 \times 10^{3} M_{\mathrm{r}}$ protein of $80 \%$ identity with reggie- 1 and $45 \%$ identity with reggie-2 is ESA (epidermal surface antigen) (Fig. 4). ESA was cloned from human keratinocytes (Schroeder et al., 1994) and subsequently identified in mouse (GenBank). Otherwise, there were no apparent homologs of reggie-1 and reggie-2.

Southern blot analysis indicated that the reggie-1 and reggie2 mRNAs are the products of different genes (data not shown). The isolation of additional partial cDNAs with significant differences to reggie-1 in the $3^{\prime}$ noncoding region suggest the existence of several gene loci of reggie- 1 .

\section{Upregulation of reggie-1 and reggie-2 mRNAs in lesioned RGCs}

In situ hybridizations with reggie- 1 and reggie- 2 cRNA probes (sense and antisense) were carried out on whole mounts of adult goldfish retinae, from which the retinal blood vessel layer had been removed in most instances. In situ hybridization signals were found in all RGCs throughout the retina at 14 and 7 days after ONS (Fig. 7). The signal was weak at 4 days and below detection level at 3 days after ONS. To confirm that these signals are specific for reggie- 1 and reggie- 2 mRNAs and not the result of unspecific crosshybridization, in vitro-transcribed full-length RNAs (sense) were subjected to northern blot analysis with reggie-1 and reggie-2 (sense and antisense) hybridization probes under the same stringency conditions used in the in situ hybridization protocol. Recognition of reggie-1 RNA by reggie-2 antisense was insignificant compared to that of reggie- 1 antisense and was as weak in signal intensity as the reggie- 1 sense probe. The same low level hybridization was found with reggie-2 RNA and reggie-1 antisense probe (and reggie-2 sense probe), whereas the appropriate pairing (reggie-2 RNA with reggie-2 antisense probe) gave a strong signal. Since these tests were performed under the same low stringency conditions as the in situ hybridization experiments in tissue, their outcome suggests that each antisense probe is specific for either reggie-1 or reggie-2.

Normal retinae were blank except for a labeled rim at the outer periphery, where the newborn RGCs are located (Fig. 7). When the blood vessel layer was left intact, in situ hybridization signals were noted along the vessels, in normal and experimental retinae. Since the blood vessel layer hinders access of the probes to the RGCs, the neurons were weakly labeled in these instances. Control retinae exposed to sense probes were blank. These in situ hybridization data are consistent with the immunohistochemical results, and demonstrate that lesion induced upregulation of reggie-1 and reggie-2 mRNAs precede reexpression of reggie proteins on the surface of the RGCs and RGC axons.

\section{DISCUSSION}

Molecules that are expressed by RGCs after injury and during regrowth of their axons may represent functional correlates of axonal regeneration. The cell surface proteins reggie- 1 and reggie- 2 are upregulated by RGCs after optic nerve lesion and are provided to the regenerating axons, indicating that both these proteins participate in regrowth or reconnection of axotomized CNS neurons. Reggie differs from the growth-associated CAMs in that the onset of lesion-induced reexpression was delayed. Moreover, molecular cloning has identified reggie-1 and reggie-2 as new neuronal cell surface proteins, both of which were isolated by mAb M802.

That the amino acid sequences derived from cloning indeed belong to the relevant neuronal surface proteins recognized by M802 in tissue is evidenced by several facts. First, recombinant reggie-1 and reggie-2 have apparent molecular weights in SDS-PAGE that are similar to that of the immunopurified M802 antigen. M802 and the antisera agaínst recombinant reggie- 1 and reggie- 2 recognize the same $48 \times 10^{3} M_{\mathrm{r}}$ band in western blots with detergent soluble membrane proteins of brain. Second, antisera against recombinant reggie-1 and reggie- 2 both recognize the same structures as M802. These are the new RGCs at the retinal margin and the young growing axons derived from these neurons in normal fish, all RGCs and $\mathrm{RGC}$ axons in the retina following optic nerve transection, and endothelial cells of blood vessels. Third, the reggie-1- and reggie-2-derived cRNA probes hybridized to mRNAs in the new RGCs in normal adult retinae and to all RGCs in retinae after optic nerve lesion. This and the overall pattern of mRNA expression of reggie-1 and reggie- 2 perfectly correlate with M802 immunoreactivity of these neurons. Thus, we believe that we have isolated forms of reggie relevant to adult RGCs, although we have isolated the proteins from total larvae and cloned full-length cDNAs from a cDNA library of 5-day-old fish.

Reggie- 1 and reggie- 2 are only $44 \%$ identical at the amino acid level. By this comparison and by Southern blot analysis, reggie- 1 and reggie- 2 are encoded by different genes. There may be further relatives of reggie- 1 and reggie- 2 forming altogether a putative reggie family. Screens with the $389 \mathrm{bp}$ cDNA of reggie- 1 and the isolation of non full-length cDNA clones whose $3^{\prime}$ non-coding sequences markedly differ from that of the four full-length cDNAs of reggie-1 indicate the existence of further forms of reggie-1. Moreover, goldfish have, for instance, three or four loci of the synapse protein SNAP-25, whereas SNAP-25 occurs as a single copy gene in mouse, chicken and Drosophila (Risinger and Larhammer, 1993). The amino acid exchanges such as those observed between the RLysC 4 peptide sequences of reggie-1 (obtained by Edmann degradation) and the predicted amino acid sequence can be interpreted as signs for the existence of further genes encoding isoforms of reggie-1.

Along with the lesion-induced expression of reggie-1 and reggie-2 mRNAs, reggie protein is seen on the RGC surface and on the regenerating axons but its appearance on the new 
(regenerating) portion of axons in vivo is delayed. The growthrelated CAMs, for instance, appear on the regenerating axons as soon as they cross the lesion (5-9 days after ONS) and throughout their path into tectum (10-40 days after ONS, reviewed in Stuermer et al., 1992; Hirsch et al., 1995). Prior to the more rapid lesion-induced appearance of these CAMs on the axonal surfaces, the mRNAs are upregulated by RGCs as early as 48 hours after optic nerve lesion (Bernhardt et al., 1996 , in press). In contrast, the first signs of reggie-1 and reggie-2 mRNA re-expression were detected at 4 days after ONS and intense signals were detected at 7 days. M802 staining on the regrowing axons in the nerve is first detected at 18 days, i.e. 10 days later than the CAMs, and in the tectum at 40 days after ONS, and increases thereafter to maximal intensity around 130 days. The growth-related CAM, neurolin, has vanished from the axons at this time (Paschke et al., 1992) and CAM E587 antigen (Vielmetter et al., 1991) and NCAM 180/140 (Bastmeyer et al., 1990) are diminished. To account for this delayed and gradually increasing expression of reggie on the new portion of axons one may hypothesize that expression of reggie protein is influenced by the interaction of the growing axons with their environment. A related phenomen was observed for the neuronal surface proteoglycan CAT-301 (Zaremba et al., 1989) whose expression is dependent on and increases with onset of neuronal activity. There are no indications, however, for an influence of neural activity on reggie expression. Functional retinotectal synapses are reformed immediately after the arrival of the retinal axons in the tectum (Stuermer and Easter, 1984; Schmidt et al., 1983). A large proportion of the first formed synaptic connections, however, are inappropriately positioned and the reformation of a retinotopically organized map of near normal precision takes several weeks (Schmidt et al., 1988; Stuermer, 1988). Intense M802 staining temporally correlates with map refinement, but also with the process of remyelination by oligodendrocytes (Wolburg, 1981; Stuermer and Easter, 1984b; Ankerhold et al., 1995) and with changes in the extracellular matrix, which presumably occur at this time. Whether reggie expression is causally linked to these events needs to be clarified. The diffuse character of M802 immunostaining on tissue sections suggests that reggie protein is steadily exported and preferentially accumulated on and around the axons in SO and SFGS of the tectum. This marked lesion-induced upregulation implies a significant but presently unknown function of reggie during axonal regeneration.

For further analysis of reggie expression, an investigation of its appearance during early development of the fish retinotectal system is desirable. For this kind of study, zebrafish are preferred over goldfish (which are season-dependent breeders) because of the regular availability of embryos and of embryo at defined stages. However, new and crossreacting antibodies are required and the zebrafish homologues of reggie-1 and reggie-2 will have to be cloned. In those goldfish embryos that we were able to test to date, reggie expression was not detected (Schulte et al., 1995).

Reggie expression is not restricted to the nervous system but present on endothelial cells of blood vessels and in skin. Staining in the blood vessel layer overlying the adult fish retina correlated with weak reggie-1 and reggie-2 in situ hybridization signals as was recognized in retinal whole mounts. Whether this correlation holds true throughout the vascular system of the brain has not been analyzed and will require an adaptation of the in situ-hybridization procedure for tissue sections. The relation of M802 staining and reggie mRNA expression outside the visual system has not been worked out. However, M802 labeling and northern blot analysis indicate the existence of reggie-1, reggie-2 or of a reggie-related protein, which may perhaps represent a teleost form of ESA.

The $35 \times 10^{3} M_{\mathrm{r}}$ epidermal surface antigen ESA (Schroeder et al., 1994) whose cDNA was isolated from human keratinocytes possesses a striking $80 \%$ identity (on amino acid level) to reggie-1. The similarities between amino acid sequences of ESA (Schroeder et al., 1994) and reggie-1 are surprisingly high given the fact that species homologs in the related tissue of fish and warm-blooded vertebrates usually diverge more markedly (Brümmendorf and Rathjen, 1994). Related molecules in different species, however, conserve amino acid residues and amino acid sequences required for preservation of their three-dimensional structure. This is the case with intracellular domains, fibronectin-like domains and Ig loops of cell adhesion molecules (Williams and Barclay, 1988, Piggot and Power, 1993). Therefore, it seems reasonable to assume that the conserved regions of ESA and reggie play similar roles, for protein folding, interaction with the cell membrane or with other proteins of the extracellular space. The deduced amino acid sequence of reggie-1, reggie-2, and ESA (Schroeder et al., 1994) are predicted to be mostly $\alpha$-helical (Predictprotein Server, EMBL, Heidelberg). The formation of coiled-coil $\alpha$-helices, which was suggested for ESA (Schroeder et al., 1994), however, seems unlikely for reggie (A. Lupas, personal communication).

The finding that reggie- 1 and reggie- 2 fail to exhibit putative membrane spanning $\alpha$-helices or consensus sequences for GPI anchor attachment (Englund, 1993), but instead posses clusters of positively charged amino acids suggests that reggie-1 and reggie- 2 may associate with the cell surface via ionic interactions as reported for collapsin (Luo et al., 1993) and the ECM proteins cytotactin/J1/tenascin (Grumet et al., 1985; Kruse et al., 1985) and Cat 301 (Zaremba et al., 1989), or that they have another noncovalent form of association with the cell surface. Reggie may be axonally released as are the above mentioned proteins as well as NCAM (Gower et al., 1988) and axonin1/Tag-1 (Ruegg et al., 1989; Furley et al., 1990). Axonin1/Tag-1 and NCAM, however, also occur as GPI-linked molecules, a mode of anchorage for cell surface molecules not observed for reggie-1, reggie-2 or ESA (Schroeder et al., 1994). However, since reggie was obtained from membranes either through exposure to detergent or high salt extraction, we cannot exclude the possibility that there are as yet unidentified forms of reggie possessing a membrane anchor or transmembrane domains.

In summary, lesion-induced upregulation of reggie- 1 and reggie- 2 by $\mathrm{RGCs}$ and the regulated expression of reggie proteins on the surface of the regenerating RGC axons suggests that reggie participates in restoration of the visual pathway. Direct functional assays and the identification of homologous genes in mammals (Lommel et al., 1996) may provide new insights into the role of reggie for neuronal recovery in the CNS.

The authors thank Dr Susanne Giordano and Mary Anne Cahill for comments on and corrections of the manuscript, and Marianne 
Wiechers and Brigitte Haag for technical assistance. Dr Martin Bastmeyer helped with retinal wholemount preparations and Richard Ankerhold helped with in situ hybridizations. This work was supported by grants of the Deutsche Forschungsgemeinschaft (DFG) to CAOS, STU-112/14-1, the Deutsche Stiftung Querschnittlähmung and by the Fonds der Chemischen Industrie (FCI).

\section{REFERENCES}

Aguayo, A. J., Rasminsky, M., Bray, G. M., Carbonetto, S., McKerracher, L., Villegas-Peres, M. P., Vidal-Sanz, M. and Carter, D. A. (1991). Degenerative responses of injured neurons in the central nervous system of adult mammals. Phil. Trans. R. Soc. Lond. 331, 337-343.

Altschul, S., Gish, W., Miller, W., Myers, E. W. and Lipman, D. W. (1990). Basic local alignment search tool. J. Mol. Biol. 215, 403-410.

Ankerhold, R., Kaethner, R.J. and Stuermer, C.A.O. (1995) Morphology of oligodendrocytes in the goldfish optic tract and their fate after optic nerve transection. Soc. Neurosci. Abstr. 20, 42.

Ausubel, F. M., Brent, R., Kingston, R. E., Moore, D. D., Seidman, J. G., Smith, J. A. and Struhl, K. (1980). Current Protocols in Molecular Biology. Greene Publishing Associates, New York:Wiley-Interscience.

Bastmeyer, M., Leppert, C., Ott, H. and Stuermer, C. A. O. (1995). Fish E587-glycoprotein a member of the L1-family of cell adhesion molecules participates in axonal fasciculation and the age-related order of ganglion cell axons in the goldfish eye. J. Cell Biol. 130, 969-976.

Bastmeyer, M., Schlosshauer, B. and Stuermer, C. A. O. (1990). The spatiotemporal distribution of NCAM in the retinotectal system of goldfish detected by the monoclonal antibody D3. Development 108, 299-311.

Bastmeyer, M., Jeserich, G. and Stuermer, C.A.O. (1994). Similarities and differences between fish optic nerve tract oligodendrocytes and Schwann cells. Glia 22, 300-314.

Benowitz, L. I. and Lewis, E. R. (1983). Increased transport of 44000-to 49000-dalton acidic proteins during regeneration of the goldfish optic nerve: a two-dimensional gel analysis. J. Neurosci. 3, 2153-2163.

Benowitz, L. I., Shashoua, V. E. and Yoon, M. G. (1981). Specific changes in rapidly transported proteins during regeneration of the goldfish optic nerve. $J$. Neurosci. 1, 300-307.

Bernhardt, R.R., Tongiorgi, E., Anzini, P. and Schachner, M. (1996). Increased expression of specific recognition molecules by retinal ganglion cells and by optic pathway glia accompanies the successful regeneration of retinal axons in adult zebrafish. J. Comp. Neurol., in press.

Breathnach, R. and Chambon, P. (1981). Organization and expression of eucaryotic split genes coding for proteins. Ann. Rev. Biochem. 50, 349-383.

Brümmendorf, T. and Rathjen, F. Eds (1994) Cell Adhesion Molecules 1: Immunoglobulin Superfamily, pp 951-979. London: Academic Press.

Burmeister, G. W., Burmeister, D. W. and Grafstein, B. (1985). Changes in protein content of goldfish optic nerve during degeneration and regeneration following nerve crush. J. Neurochem. 44, 1142-1151.

Doster, S. K., Lozano, A. M., Aguayo, A. J. and Willard, M. B. (1991). Expression of the growth-associated protein GAP-43 in adult rat retinal ganglion cells following axon injury. Neuron 6, 635-647

Easter, S. S., Bratton, B. and Scherer, S. S. (1984). Growth-related order in the retinal fiber layer of goldfish. J. Neurosci. 4, 2173-2190.

Easter, S. S., Rusoff, A. C. and Kish, P. E. (1981). The growth and organisation of the optic nerve and tract in juvenile and adult goldfish. $J$. Neurosci. 1, 793-811.

Eckerskorn, C. W., Newes, H., Goretzky, H. and Lottspeich, F. (1988). A new siliconized glass fiber as support for protein-chemical analysis of electroblotted proteins. Eur. J. Biochem. 176, 509- 519.

Eckerskorn, C. W. and Lottspeich, F. (1989). Internal amino-acid sequenceanalysis of proteins separated by gel-electrophoresis after tryptic digestion in polyacrylamide matrix. Chromatographia 28, 92-94.

Engel, J. (1989). EGF-like domains in extracellular matrix proteins: localized signals for growth and differentiation? FEBS Lett. 251, 1-7.

Englund, P. T. (1993). The structure and biosysnthesis of glycosyl phosphatidylinositol protein anchors. Ann. Rev. Biochem. 62, 121-138.

Furley, A. J., Morton, S. B., Manalo, D., Karagogeos, D., Dodd, J. and Jessell, T. (1990). The axonal glycoprotein TAG-1 is an immunoglobulin superfamily member with neurite outgrowth-promoting activity. Cell 61, 157-170.

Gower, H. J., Barton, C. H., Elsom, V. L., Thompson, J., Moose, S. E.,
Dickson, G. and Walsh, F. S. (1988). Alternative splicing generates a secreted form of NCAM in muscle and brain. Cell 55, 955-964.

Grafstein, B. (1991). The goldfish visual system as a model for the study of regeneration in the central nervous system. Development and Plasticity of the Visual System. In Vision and Visual Dysfunction. Vol II (ed. J. R. CronleyDillon), pp 190-205, London: Mac Millan.

Grafstein, B. and McQuarrie, I. G. (1978). Role of nerve cell body in axonal regeneration. In Neuronal Plasticity (ed. C. Cotman), pp. 155-195. New York: Raven Press.

Grumet, M., Hoffman, K. L. and Edelman, G. M. (1985). Cytotactin an extracellular matrix protein of neural and non-neural tissues that mediates glia-neuron interaction. Proc. Natl. Acad. Sci. USA 82, 8075-8079.

Heukeshoven, J. R. (1985). Simplified method for silver staining of proteins in polyacrylamide gels and the mechanism of silver staining. Electrophoresis $\mathbf{6}$, 103-112.

Hirsch, S., Cahill, M. A. and Stuermer, C. A. O. (1995). Fibroblasts at the transection site of the lesiond goldfish optic nerve. J. Comp. Neurol. 360 , 599-611.

Johns, P. A. (1977). Growth of the adult goldfish eye: III Source of the new retinal cells J. Comp. Neurol. 176, 343-357.

Kruse, J., Keilhauer, G., Faissner, A., Timp, R. and Schachner, M. (1985). The J1 glycoprotein - a novel nervous system cell adhesion molecule of the L2/HNK-1 family. Nature 316, 146-148.

Kyte, J. and Doolittle, R. (1982). A simple method for displaying the hydropathic character of a protein. J. Mol. Biol. 15, 105-132.

LaBate, M. and Skene, J. H. P. (1989). Selective conservation of Gap-43 structure in vertebrate evolution. Neuron 3, 299-310.

Laemmli, U. K. (1970). Cleavage of structural proteins during the assembly of the head of bacteriophage T4. Nature 227, 680- 685 .

Laessing, U., Giordano, S., Stecher, B., Lottspeich, F. and Stuermer, C. A. O. (1994). Molecular characterization of fish neurolin: a growth associated cell surface protein and member of the immunoglobulin superfamily in the fish retinotectal system with similarities to chick protein DM-GRASP/SC1/BEN. Differentiation 56, 21-29.

Lanners, H. N. and Grafstein, B. (1980). Early stages of axonal regeneration in the goldfish optic nerve tract: an electron microscopic study. J. Neurocytol. 9, 733-751.

Luo, Y., Raible, D. and Raper, J. (1993). Collapsin: A protein in brain that induces the collapse and paralysis of neuronal growth cones. Cell 75, 217 227.

Lommel, S., Schulte, T., Jung, M. and Stuermer, C. A. O. (1996). Identification of reggie-1 and reggie-2, two members of a family of cell surface proteins in fish and mammals. Int. J. Devl. Neurosci. 14 (Suppl. 1), 85 .

Lupas, A., van Dyke, M. and Stock, J. (1991). Predicting coiled coils from protein sequences. Science 252, 1162-1164.

Meyer, R. L., Sakurai, K. and Schauwecker, E. (1985). Topography of regenerating optic fibers in goldfish traced with local wheat germ injections into retina: evidence for discontinuous microtopography in the retinotectal projection. J. Comp. Neurol. 239, 27-43.

Moran, P. and Caras, I. W. (1991a). Fusion of sequence elements from nonanchored proteins to generate a fully functional signal for glycophosphatidylinositol membrane anchor attachment. J. Cell. Biol. 115,1595-1600.

Moran, P. and Caras, I. W. (1991b). A nonfunctional sequence converted to a signal for glycophosphatidylinositol membrane anchor attachment. J. Cell. Biol. 115, 1595-1600.

Mount, S. M. (1982). A catalogue of splice junction sequences. Nucl. Acids Res. 10, 459-472.

Paschke, K. A., Lottspeich, F. and Stuermer, C. A. O. (1992). Neurolin, a cell surface glycoprotein on growing axons in the goldfish visual system is reexpressed during retinal axonal regeneration. J. Cell Biol. 117, 863-875.

Perry, G. W., Burmeister, D. W. and Grafstein, B. (1987). Fast axonally transported proteins in regenerating goldfish optic axons. J. Neurosci. 7, 792806.

Piggot, R. and Power, C. (1993). The Adhesion Molecule Facts Book. London: Academic Press

Risinger, C. and Larhammar, D. (1993). Multiple loci for synapse protein SNAP-25 in the tetraploid goldfish. Proc. Natl. Acad. Sci. USA 90, 1059810602.

Ruegg, M. A., Stoeckli, E. T., Kuhn, T. B., Heller, M., Zuellig, R. and Sonderegger, P. (1989). Purification of axonin-1 a protein that is secreted from axons during neurogenesis. EMBO J. 8, 55-63.

Sambrock, J., Fritsch, E. F. and Maniatis, T. (1989). Molecular Cloning: A 
Laboratory Manual, $2^{\text {nd }}$ Edition, Cold Spring Harbor New York: Cold Spring Harbor Laboratory Press.

Schmidt, J. T., Edwards, D. L. and Stuermer, C. A. O. (1983) The reestablishment of synaptic transmission by regenerating optic axons in goldfish: Time course and effects of blocking activity by intraocular injection of tetrodotoxin. Brain Res. 269, 15-17.

Schmidt, J. T., Turcotte, J. C., Buzzard, M. and Tieman, D. G. (1988) Staining of regenerated optic arbors in goldfish tectum: Progressive changes in immature arbors and a comparison of mature regenerated arbors with normal arbors. J. Comp. Neurol. 269, 565-591.

Scholes, J. H. (1979). Nerve fibre topography in the retinotectal projection to the tectum. Nature 278, 620-624.

Schroeder, W., Stewart-Galetka, S., Mandavilli, S., Parry, D. A., Goldsmith, D. and Duvic, M. L. (1994). Cloning and characterization of a novel epidermal cell surface antigen (ESA). J. Biol. Chem. 269, 1998319991.

Schulte, T., Lottspeich, F. and Stuermer, C. A. O. (1994). Molecular characterization of reggie antigen: a growth-asssociated cell surface protein in the retinotectal system of goldfish. Soc. Neurosci. Abstr. 20, 1080.

Schulte, T., Lottspeich, F. and Stuermer, C. A. O. (1995). Characterization of reggie-1 and isolation of reggie-2,-cell surface proteins of the goldfish CNS. Soc. Neurosci. Abstr. 21, 795.

Skene, J. H. P. (1989). Axonal growth-associated proteins. Annu. Rev. Neurosci. 12, 127-156.

Stuart, R. A., Neupert, W. and Tropschlug, M. (1987). Deficiency in mRNA splicing in a cytochrome c mutant of Neurospora crassa: Importance of carboxy terminus for import of cytochrome c into mitochondria. EMBO J. 6, 2131-2137.

Stuermer, C. A. O. (1988) The trajectories of regenerating retinal axons in the goldfish tectum. II. Exploratory branches and growth cones on axons at early regeneration stages. J. Comp. Neurol. 267, 69-91.

Stuermer, C. A. O. and Easter, S. S. (1984a). Rules of order in the retinotectal fascicles. J. Neurosci. 4, 1045-1051.
Stuermer, C. A. O. and Easter, S. S. (1984b). A comparison of the normal and regenerated retinotectal pathways of goldfish. J. Comp. Neurol. 223, 57-76.

Stuermer, C. A. O., Bastmeyer, M., Bähr, M., Strobel, G. and Paschke, K. (1992). Trying to understand axonal regeneration in the CNS of fish. $J$. Neurobiol. 23, 537-559.

Thompson, J. D., Higgins, D. J. and Gibson, T. J. (1994). CLUSTALW: improving the sensitivity of progressive multiple sequence alignment through sequence weighting, position-specific penalties and weight matrix choice. Nucl. Acids Res. 22, 4673-4680.

Towbin, H., Staehelin, T. and Gordon, J. (1979). Electrophoretic transfer of proteins from acrylamide gels to nitrocellulose sheets: procedure and some applications. Proc. Natl. Acad. Sci. USA 76, 4350-4354.

Vielmetter, J., Lottspeich, F. and Stuermer, C. A. O. (1991). The monoclonal antibody E587 recognizes growing (new and regenerating) retinal axons in the goldfish retinotectal pathway. J. Neurosci. 11, 3581-3593.

Vielmetter, J. and Stuermer, C. A. O. (1989). Goldfish retinal axons respond to position-specific properties of tectal cell membranes in vitro. Neuron $\mathbf{2}$, 1331-1339.

Westerfield, M. (1994). The Zebrafish Book. A Guide for the Laboratory Use of Zebrafish (Brachydanio rerio). Eugene Oregon:University of Oregon Press.

Wilkinson, D. G. (1992). In Situ Hybridization, A Practical Approach. Oxford: IRL Press at Oxford University Press.

Williams, A. F. and Barclay, A. N. (1988). The immunoglobulin superfamily domains for cell surface recognition. Annu. Rev. Immunol. 6, 381-405.

Wollburg, H. (1981) Myelination and remyelination in the regenerating visual system of the goldfish. Exp. Brain Res. 43, 199-206.

Zaremba, S., Guimaraes, A., Kalb, R. G. and Hockfield, S. (1989). Characterization of an activity dependent neuronal surface proteoglycan identified with monoclonal antibody Cat-301. Neuron 2, 1207-1219.

(Accepted 30 October 1996) 